TAO, Vol. 16, No. 4, 865-883, October 2005

\title{
Characterization of the Pleistocene Volcanic Chain of the Bicol Arc, Philippines: Implications for Geohazard Assessment
}

\author{
Eric S. Andal ${ }^{1}$, a , Graciano P. Yumul, Jr. ${ }^{1,}$ 2, *, Eddie L. Listanco ${ }^{1}$, \\ Rodolfo A. Tamayo, Jr. ${ }^{1}$, Carla B. Dimalanta ${ }^{1}$ and Teruaki Ishii ${ }^{3}$
}

(Manuscript received 15 May 2004, in final form 20 July 2005)

\begin{abstract}
Several active volcanic arcs are present in the Philippine Mobile Belt, the region enclosed by the Philippine Trench and the Manila-NegrosCotabato Trench systems. One of the most prominent among them is the Bicol Arc, a $\sim 260 \mathrm{~km}$ long volcanic arc located in the central-eastern margin of the Philippine Mobile Belt. The Bicol Arc hosts three of the active volcanoes in the country, including the Mayon Volcano, which has erupted repeatedly within the last decade. Aside from the three active volcanoes, there are at least nine other Pleistocene major volcanic centers that make up the volcanic arc. Although the rocks from the arc range in composition from basalt to rhyolite, they are mostly basaltic andesites and andesites. Magma mixing and fractional crystallization accompanied the generation of these rocks. The rocks exhibit typical island arc geochemical signatures. In addition, the $\mathrm{Sr}$ and $\mathrm{Y}$ ratio plots suggest that the Bicol Arc is mainly composed of mantle-wedge derived magmas with some samples from Bacon-Manito and Culasi showing similarities to adakites. Along-arc geochemical variation may be related to the variation in crustal thickness of the volcanic arc. The petrological and geochemical characterizations of the rocks provide information on how the volcanic centers evolved. This is important in assessing the attendant geohazards related to this volcanic arc.
\end{abstract}

\footnotetext{
${ }^{1}$ National Institute of Geological Sciences, College of Science, University of the Philippines, Diliman, Quezon City, Philippines

2 Philippine Council for Industry and Energy Research and Development, Department of Science and Technology, Bicutan, Taguig, Philippines

${ }^{3}$ Ocean Research Institute, University of Tokyo, Nakano-ku, Tokyo, Japan

a Now at the Department of Earth Sciences, Faculty of Science, Kanazawa University, Kanazawa, Japan

* Corresponding author address. Prof. Graciano P. Yumul, Jr., National Institute of Geological Sciences, College of Science, University of the Philippines, Diliman, Quezon City, Philippines; E-mail:rwg@i-next.net
} 


\section{(Key words: Volcanic arc, Petrography, Geochemistry, Geohazard, Southeastern Luzon, Philippines.)}

\section{INTRODUCTION}

Volcanic eruptions are one of the common natural phenomena that have wrought havoc, destroyed properties and taken human lives on several occasions. Areas situated within the Pacific Ring of Fire are particularly susceptible to the dangers posed not only by the eruption of volcanoes but also by other volcano-related hazards (e.g., Newhall and Punongbayan 1996; Chertkoft and Gardner 2004). In addition to volcanic eruptions, population centers also suffer from the devastation inflicted by amphitheater or crater collapse, lahars, pyroclastic flows, debris avalanches, volcanic quakes and volcanic gases (e.g., Wallace 2001; Lee et al. 2005; Pecoraino and Giammanco 2005). Scientists have, on numerous occasions, studied volcanoes and volcanic eruptions in order to characterize these volcanic eruption-related processes and to determine whether there is a pattern in their behavior. Moreover, these investigations assess the hazards associated with the volcanoes as well as offer measures that will help develop proactive measures and planning in case of any future eruptions.

The Philippine archipelago, which lies at the junction of two oppositely-dipping subduction zones, is characterized by several volcanic arcs (e.g., Yumul et al. 2003a, b). On its western side, subduction along the east-dipping Manila-Negros-Cotabato trench system produced the Taiwan-Luzon, Negros-Masbate and Cotabato arc systems. The volcanic arc on the eastern side of the archipelago resulted from the subduction of the Philippine Sea Plate along the west-dipping Philippine Trench. An important segment of this volcanic arc is represented by the Bicol Arc, which stretches from Camarines Norte to Sorsogon in the Bicol Peninsula (Fig. 1a). In the Bicol Arc, there are at least twelve identified eruptive centers and volcanic complexes (Fig. 1b). Three of the twelve - Mayon, Iriga and Bulusan - are categorized by the Philippine Institute of Volcanology and Seismology as active volcanoes. The rest of the volcanic centers are inactive but are considered relatively young based on radiometric dating $(<0.1-6.96 \mathrm{Ma}$ ) (Ozawa et al. 2004) and morphology. This paper focuses on the youngest magmatic episode in the Bicol Arc. The petrography and geochemistry of these young volcanic centers are presented. Data from the literature and new whole rock geochemical analyses are utilized in the geochemical characterization (Table 1). It is hoped that the results of this investigation will contribute to our understanding of the magmatic processes associated with these volcanoes. In addition, the results can provide useful background information for the successful assessment of the hazards that usually accompany volcanic eruption processes.

\section{REGIONAL GEOLOGIC SETTING}

The Bicol Arc is located at the southeastern portion of Luzon, the largest island in the Philippine archipelago. The elongated landmass occupied by the Bicol Arc, which stretches some $260 \mathrm{~km}$, is oriented northwest-southeast and covers an area of $\sim 15237.86 \mathrm{sq}$. km. This region is sandwiched between two major tectonic structures, namely, the Philippine Trench 


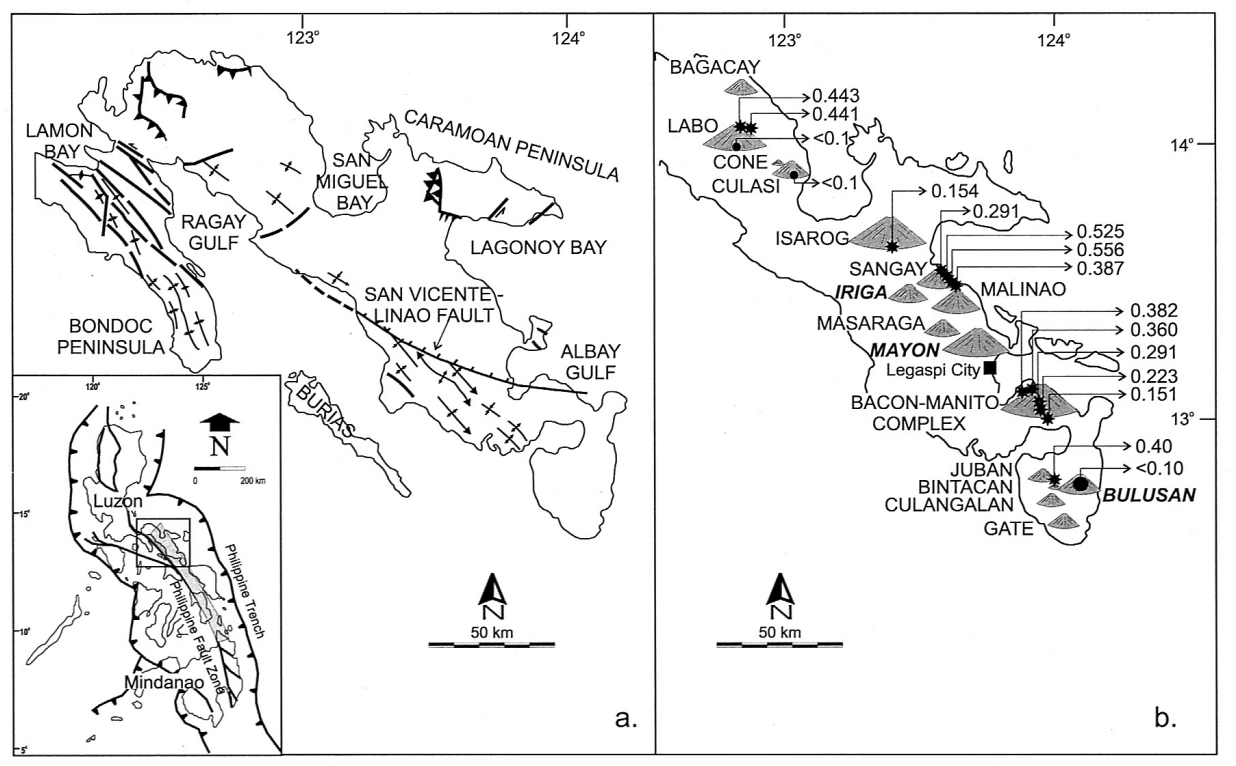

Fig. 1. Regional maps of the study area. Inset shows the map of the Philippines showing its general tectonic features. The Philippine Trench is located on the eastern side of the Southeastern Luzon volcanic arc (boxed area) whereas the western side is bounded by the central segment of the Philippine Fault Zone. Gray shaded area is the volcanic arc related to subduction along the Philippine Trench. (a) Map showing the geological structures that control the elongated shape of the Bicol region (Andal, 2002 and references therein). (b) The Bicol Arc is composed of at least twelve volcanic centers and complexes that include three active volcanoes (Mayon, Iriga and Bulusan). Numbers correspond to K-Ar age datings ( - from Ozawa et al. 2004; - from JICA 1999).

and the Philippine Fault Zone (inset in Fig. 1a). The Philippine Trench is located on the eastern side of the Bicol Arc and is approximately 210 to $280 \mathrm{~km}$ offshore. Along this trench, the Philippine Sea Plate subducts westward under the Philippine Archipelago at an average rate of $8 \mathrm{~cm}$ per year (e.g., Aurelio 2000). Arc volcanism during the Plio-Pleistocene is believed to be related to this subduction. The volcanic arc corresponding to subduction along the Philippine Trench can be traced from the Bicol region to Leyte but becomes unclear in Mindanao (Sajona et al. 1996; Ozawa et al. 2004). On the western side of the Bicol Arc lies the central segment of the Philippine Fault Zone, an active left-lateral strike-slip fault cutting the Philippine archipelago along its length. The Philippine Fault Zone is traced some $20-40 \mathrm{~km}$ offshore to the southwest of the mainland passing through Burias Island and Bondoc Peninsula, cutting through 


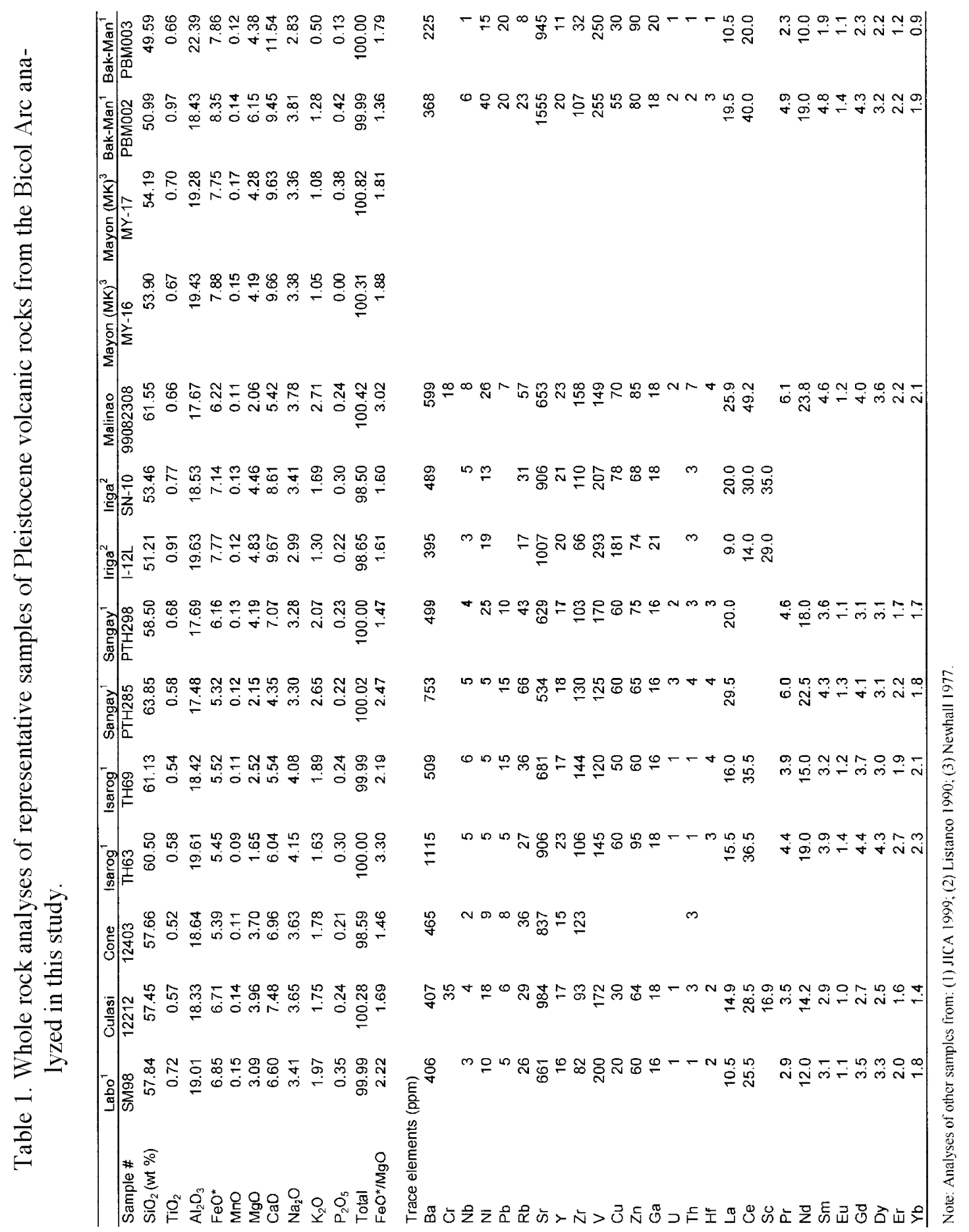


Calauag, Quezon area and exiting into Lamon Bay (Fig. 1a). The Philippine Trench and the Philippine Fault Zone dictate the elongated shape of the region and have major influences on the local structures in the arc which are mostly oriented northwest-southeast. Transecting the arc is the San Vicente-Linao Fault (Fig. 1a). It cuts through the Pocdol Mountains (BaconManito area), southwestern side of Legaspi and Mayon Volcano in a west-northwesterly orientation. Another set of NW-SE trending faults defines the Albay and Lagonoy Gulf [Newhall 1977; Japan International Cooperation Agency (JICA) 1999].

The Bicol Arc shows the typical stratigraphy of volcanic arc in the Philippines. The sequence has an ultramafic and metamorphic rock basement overlain by volcanic materials, limestones and deep marine sediments. The overlying volcanic materials occur as primary flows or are remobilized and deposited by sedimentary processes. Through the evolution of the arc, alternating terrestrial and marine sedimentary rocks are deposited. Structural features also play a major role in the evolution of the arc (Listanco 1990; Lagmay et al. 2000). This is especially true in the case of the Bicol Arc because of its proximity to major tectonic structures. Volcanic materials of more recent eruptions (Pleistocene) blanket the older volcanic, volcaniclastic and clastic layers. Pleistocene to Holocene carbonates, clastic rocks and alluvium cover the low-lying areas of the emerged volcanic arc.

\section{THE BICOL VOLCANIC ARC}

The Bicol Arc has undergone at least three stages of magmatism during its evolutionary history (Andal 2002). Each episode is distinguished from the others mainly by age and geochemical differences. Intrusive (e.g., Paracale Granodiorite) and volcaniclastic (e.g., Larap and Ragay Volcanics) rocks of intermediate to silicic composition characterize the oldest subductionrelated rocks, dated $\sim 70$ - $6 \mathrm{Ma}$ (Ozawa et al. 2004), and comprise the first magmatic stage. A second batch of volcanic rocks dated between 6 - 1 Ma followed the initial magmatic stage. This batch consists of basaltic andesite and dacite/rhyolite. The youngest of the three magmatic episodes is represented by the current chain of strato-volcanoes lined along the entire length of the arc (Table 2). Although it consists of volcanic rocks erupted less than 1.0 Ma up to the present, most of these volcanic centers are dated to 0.5 to $0.1 \mathrm{Ma}$ (e.g., Ozawa et al. 2004) (Fig. 1b). Active volcanic centers in the Bicol Arc are younger than 0.1 Ma. In contrast to the non-active volcanoes, they display poorly dissected cones.

Labo Volcano at the northwestern end of the Bicol Arc is a stratovolcano with a height of $\sim 1600 \mathrm{~m}$ above sea level (asl) and its base measures $\sim 24 \mathrm{~km}$ in diameter (Fig. 1b). It is composed of interlayered andesitic and dacitic lava flows and breccias (Divis 1980). Culasi and Cone belong to one volcanic field, which covers an area of approximately $270 \mathrm{sq} . \mathrm{km}$. Andesites and dacites dominate this volcanic field (JICA 1999). Southeast of this volcanic field lies Isarog Volcano, which rises to a height of approximately $2000 \mathrm{~m}$ asl. The base of the cone has a diameter of $\sim 25$ kilometers. This volcanic center is made up mostly of andesite with minor dacite (Andal 2002). Sangay, a geomorphologically-dissected volcano, has a summit elevation of $850 \mathrm{~m}$ asl. It is comprised mainly of basaltic andesite and dacite. Massive lava flows exposed along its cliff-forming lava fronts are massive to highly jointed (Andal 2002). Malinao 


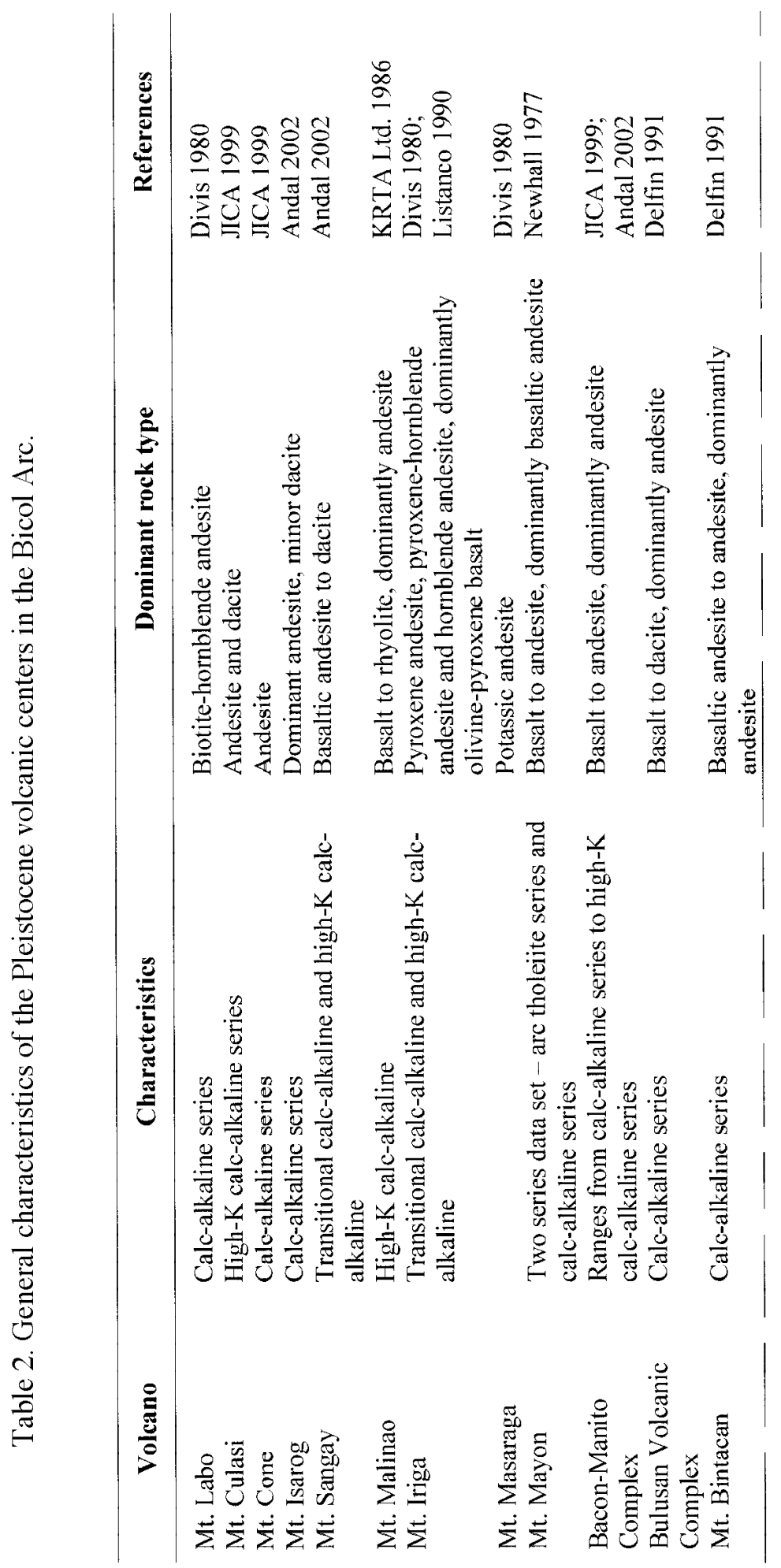


Volcano, an inactive stratovolcano located in the central part of the Bicol Arc, is $1548 \mathrm{~m}$ asl with a base diameter of $\sim 15 \mathrm{~km}$. The deep erosional gorge that characterizes the southwest flank of Malinao Volcano terminates in an alluvial fan along the beach (KRTA Ltd. 1986). Mayon Volcano, the most active among the Quaternary volcanoes in the country, rises to a height of $\sim 2500 \mathrm{~m}$ asl with a base diameter of $\sim 20 \mathrm{~km}$. It is composed of alternating layers of air fall, pyroclastic flow deposits, lava flow deposits and surge deposits. The eruptions of Mayon Volcano are usually characterized by aa and blocky lava flows. The most dominant rock type is basaltic andesite (Newhall 1977; Castillo and Newhall 2004). The Bacon-Manito volcanic complex, located southeast of Mayon Volcano, consists of a triangular-shaped topographic high with multiple eruption centers. This volcanic complex covers an area of $\sim 225 \mathrm{sq} . \mathrm{km}$. and the highest peak has an elevation of $\sim 1100 \mathrm{~m}$ asl. The western half of the complex exhibits a dissected morphology whereas well-formed volcanic cones characterize the eastern portion. Its rocks vary from basaltic andesite to andesite but are dominated by andesites (JICA, 1999). At the southeastern tip of the Bicol Arc lies the Bulusan Volcanic Complex. Aside from Bulusan Volcano, which is sitting within the Irosin caldera, there are eight cones in this complex (in the discussion, samples from the caldera wall will be referred to as Irosin). One of these cones is Bintacan, located to the northwest of the caldera. Bulusan Volcano rises to a height of $1565 \mathrm{~m}$ asl and covers an area of $\sim 900 \mathrm{sq}$. km. Phreatic, strombolian and caldera-forming eruptions typify the eruptions of Bulusan Volcano. Its rocks vary from basalt to dacite but are dominated by andesites (Delfin et al. 1993).

\subsection{Petrography}

The petrographic analysis of representative samples from some of the Pleistocene volcanic centers is presented here.

\subsubsection{Isarog}

Hornblende andesites are the most abundant rock type collected from Isarog Volcano. Fresh samples show a porphyritic texture (Fig. 2a) with glomeroporphyritic patches. Plagioclase, pyroxene and hornblende pheonocrysts attain sizes up to $2 \mathrm{~mm}$. Abundant euhedral to subhedral dusty plagioclase crystals display oscillatory zonation. Some euhedral coarse-grained plagioclase xenocrysts show resorbed cores with healed rims. The original resorbed margin of the crystal can still be traced suggesting that they were originally not in equilibrium with the host melt. Coarse-grained hornblendes sometimes exhibit resorbed texture as well as ophacitized boundaries. Hornblende laths are often intergrown with pyroxene crystals. The groundmass is fine-grained.

\subsubsection{Sangay}

Samples collected from the Sangay Volcano are dominantly pyroxene andesites. The samples are generally porphyritic and are dominated by plagioclase phenocrysts that are up to $\sim 3 \mathrm{~mm}$ in size. Plagioclase phenocrysts are subhedral to euhedral with well-developed albite twinning. On the other hand, plagioclase xenocrysts appear cloudy and sometimes 
glomeroporphyritic. They usually have resorbed margins, with some showing resorbed cores and healed margins. Furthermore, they also have concentric compositional zoning. Clinopyroxene grains are usually smaller, sometimes equant but have rounded edges. Occasional olivine grains with maximum size of $\sim 1 \mathrm{~mm}$ have euhedral shape but are altered or serpentinized. Amphibole is also observed as phenocrysts and reaches up to $\sim 5 \mathrm{~mm}$. Occasionally, the amphibole contains orthopyroxene inclusions. Nearly all amphibole grains are subhedral to euhedral but have rounded edges and are ophacitized (Fig. 2b). The groundmass is trachytic. As will be expounded later on, magma mixing appears to be a significant process during the formation of the Sangay Volcano.

\subsubsection{Bacon-Manito Volcanic Complex}

Pyroxene andesites dominate the Bacon-Manito volcanic complex. Less abundant are hornblende andesites, biotite-bearing andesites, basaltic andesites and dacites (KRTA Limited

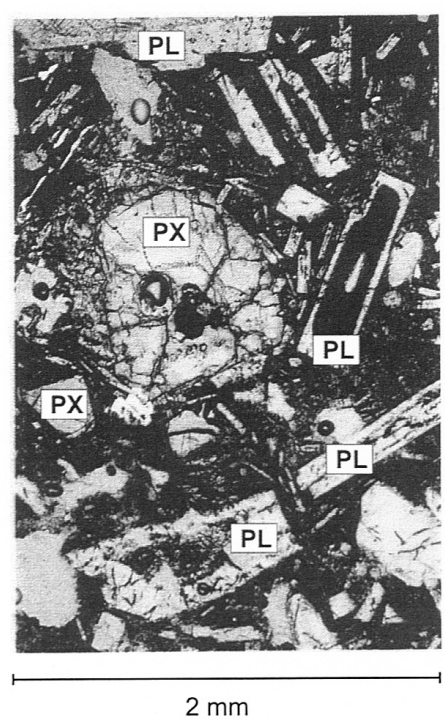

a.

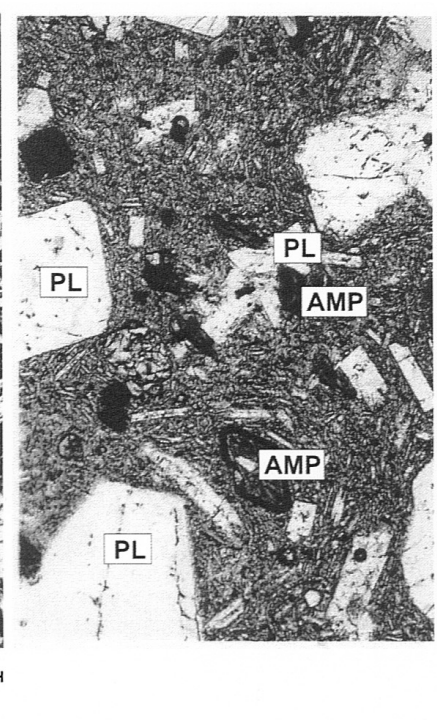

b.

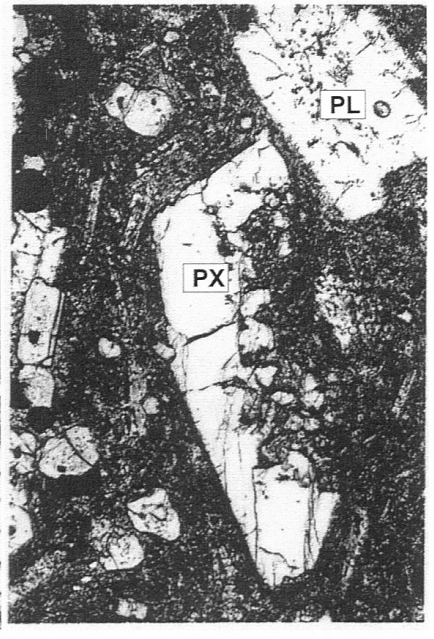

C.

Fig. 2. Photomicrographs of representative samples from some of the Pleistocene volcanic centers. (a) Andesite from Isarog showing euhedral plagioclase (PL) crystals with dusty cores. Also shown is a zoned clinopyroxene (PX) with resorbed borders rimmed by plagioclase laths. (b) Sangay andesite showing plagioclase and hornblende (AMP) phenocrysts set in a groundmass exhibiting flow texture. It also shows several amphibole with ophaticized margins. (c) Andesite from the Bacon-Manito volcanic complex showing clinopyroxene with resorbed embayment. Width of photo $=2 \mathrm{~mm}$. 
1986). The samples show a porphyritic texture (Fig. 2c). Plagioclase phenocrysts are subhedral to euhedral with oscillatory zoning and commonly show undulatory extinction. Clinopyroxene is also medium to coarse-grained and is also subhedral to euhedral. Some coarse-grained pyroxene xenocrysts are intergrown with plagioclase forming sub-ophitic texture. Amphiboles are also coarse-grained with some showing ophacitized boundaries. The groundmass is finegrained.

\subsection{Geochemistry of the Pleistocene Magmatic Episode Rocks}

New whole rock geochemical analyses of samples collected from the Bicol Arc were obtained using the X-ray fluorescence at the Ocean Research Institute, University of Tokyo and in Kyoto University, Japan. The analytical procedures, accuracy and precision of the analyses are similar to those described in Haraguchi et al. (2003) and Ozawa et al. (2004). In this paper, emphasis is placed on the geochemical characterization of the youngest episode of magmatism, thereby allowing us to understand how the young volcanic centers pose risk in terms of eruptions as well as other concomitant hazards. The chemistry of the Pleistocene magmatic episode rocks varies widely. Silica $\left(\mathrm{SiO}_{2}\right.$ wt\%) composition ranges from $48-73$ (wt\%), which encompass the range of volcanic rocks from basalt to rhyolite. Table 2 presents a summary of the general characteristics of the Pleistocene Bicol Arc deposits based on the $\mathrm{SiO}_{2}-\mathrm{K}_{2} \mathrm{O}$ plot of the samples (Fig. 3). Basaltic andesites and andesites are the dominant rock types representing the third magmatic episode. Although the majority of the rocks plot within the calc-alkaline series, some also plot in the high-K calc-alkaline series and most of the samples cluster near the boundary between the calc-alkaline and the high-K calc-alkaline series. Furthermore, some rocks from Mayon, Bacon-Manito, Iriga and Bulusan plot within the arc tholeiite series field. Plots of the rocks in the $\mathrm{MnO}-\mathrm{TiO}_{2}-\mathrm{P}_{2} \mathrm{O}_{5}$ diagram (Fig. 4; Mullen, 1983) are consistent with the $\mathrm{SiO}_{2}-\mathrm{K}_{2} \mathrm{O}$ classification scheme. That is, majority of the samples plot in the calc-alkaline basalt. These plots also show that a few samples from Mayon and Malinao and the Bacon-Manito volcanic complex plot in the island arc tholeiite field. The samples collected, based on these diagrams, are all subduction-related.

Harker-type plots of the major element concentrations of samples from Isarog, Malinao, Bintacan, Mayon, Iriga and Bulusan show both positive and negative linear slopes (Fig. 5). Mayon, Iriga and Bulusan show almost the same elemental behaviors. The $\mathrm{Al}_{2} \mathrm{O}_{3}, \mathrm{CaO}, \mathrm{FeO} *$ (total iron), $\mathrm{MgO}$ and $\mathrm{TiO}_{2}$ all decrease as fractionation progresses. The $\mathrm{K}_{2} \mathrm{O}$ is incompatible and increases as crystallization proceeds. The steady decrease in the amount of $\mathrm{Al}_{2} \mathrm{O}_{3}, \mathrm{CaO}$, $\mathrm{FeO}^{*}$ (total iron), $\mathrm{MgO}$ during fractionation suggests the crystallization of plagioclase, pyroxenes, hornblende and Ti-oxide minerals. This is consistent with the petrography of these rocks. No obvious patterns are notable in the other volcanic centers.

The multi-element plots (normalized to the primitive mantle values of Sun and McDonough 1989) of the rocks show similar patterns characterized by a steady increase from the heavy rare earth elements (HREEs) toward the large ion lithophile elements (LILEs) and depletion in high field strength elements (HFSEs) (Fig. 6). Strong $\mathrm{Nb}$ and Ti negative anomalies as well as $\mathrm{Sr}$ and $\mathrm{Pb}$ positive anomalies suggest affinity with subduction-related setting (Arculus 1994).

The sample set was divided into three segments, based on geographic location, with Labo, 


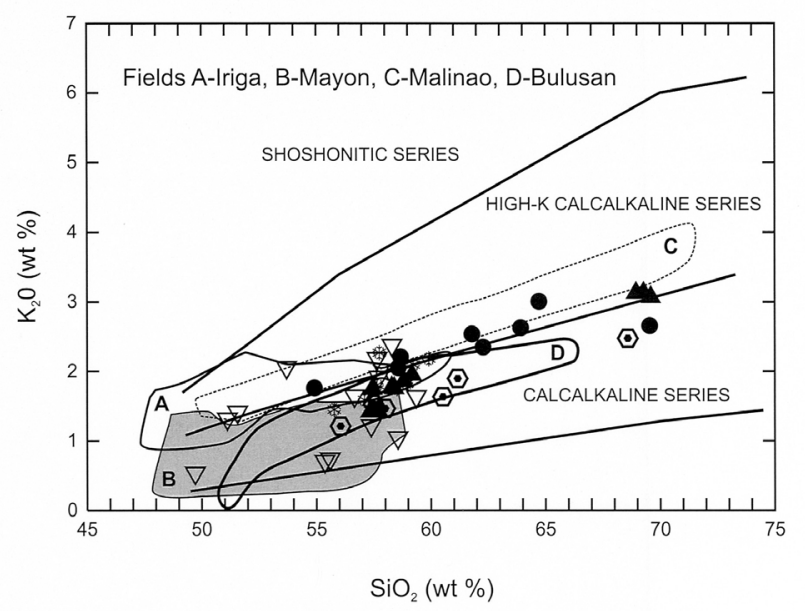

Fig. 3. $\mathrm{K}_{2} \mathrm{O}-\mathrm{SiO}_{2}$ plots of samples from: A - Iriga (Listanco 1990); B Mayon (Newhall 1977; Castillo and Newhall 2004); C - Malinao (KRTA Ltd. 1986); D - Bulusan (Delfin 1991) and - Isarog (this study). Other sources: Divis 1980; Knittel-Weber and Knittel 1990 and Japan International Cooperation Agency (JICA) 1999. Fields after Pecerillo and Taylor (1976). Isarog and Malinao are inactive volcanoes. Mayon, Iriga and Bulusan are active volcanoes. Symbols: $\boldsymbol{\Xi}$ - Labo; $\boldsymbol{\Delta}$ - Culasi; - Cone; - Sangay; $\nabla$ - Bacon Manito.

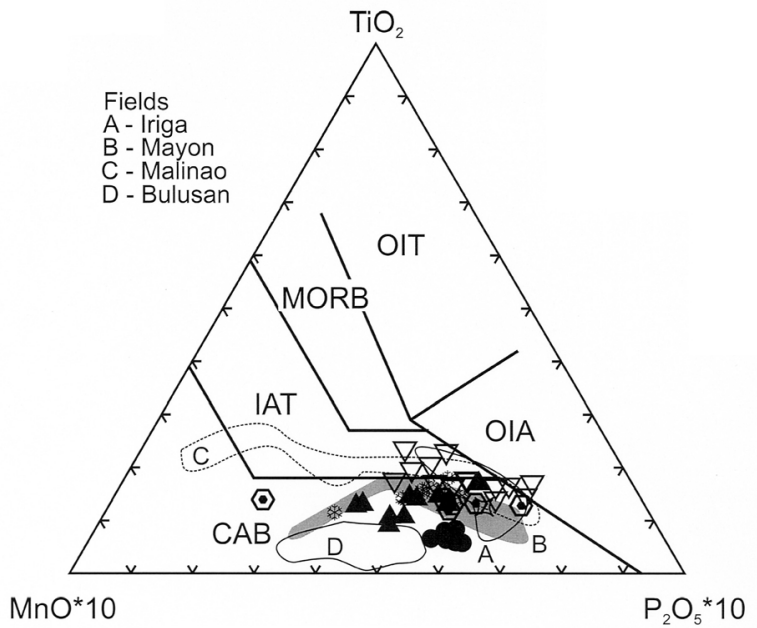

Fig. 4. The Pleistocene volcanic rocks in Southeastern Luzon mostly plot in the calc-alkaline basalt and island arc tholeiite fields. This suggests that the rocks are dominantly subduction-related. Diagram after Mullen (1983). See text for details. Symbols and references as in Fig. 3. 

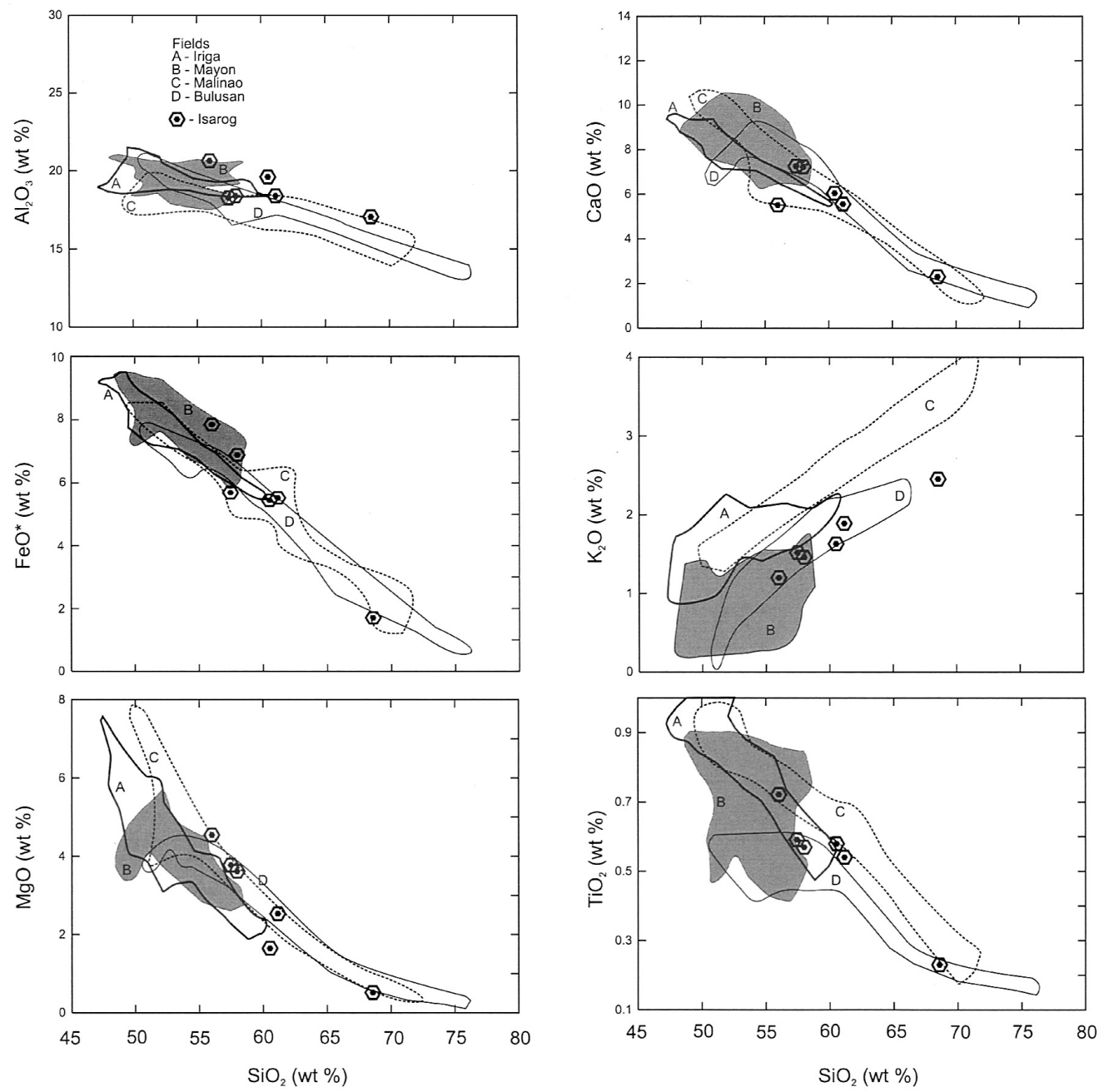

Fig. 5. Harker diagrams for major elements of samples from the different Pleistocene volcanic arcs from Southeastern Luzon. Symbols and references are shown as in Fig. 3.

Culasi and Cone representing the NW segment; Isarog, Sangay and Malinao composing the central segment volcanoes; and the Bacon-Manito complex and Bulusan corresponding to the $\mathrm{SE}$ segment. The samples were plotted in the $\mathrm{Sr} / \mathrm{Y}$ versus $\mathrm{Y}$ diagram. The samples from the NW segment volcanoes in the $\mathrm{Sr} / \mathrm{Y}$ versus $\mathrm{Y}$ diagram lie within the adakite field, although most of them plot in the transition between adakites and typical arc rocks (Defant and Drummond 1990) (Fig. 7). In contrast, most of the samples from the central segment volcanoes plot within 


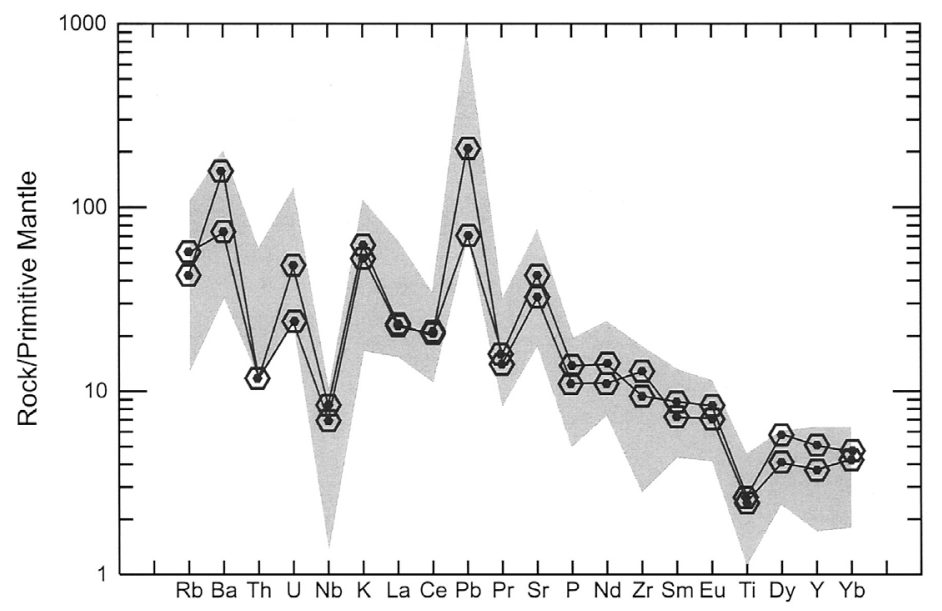

Fig. 6. Multi-element diagram of trace and rare earth element compositions of Pleistocene volcanic rocks from Isarog normalized to Primitive Mantle. Normalizing values are from Sun and McDonough (1989). Shaded region represents the whole range of composition for all samples. They show typical calc-alkaline signature. Symbols and references as in Fig. 3.

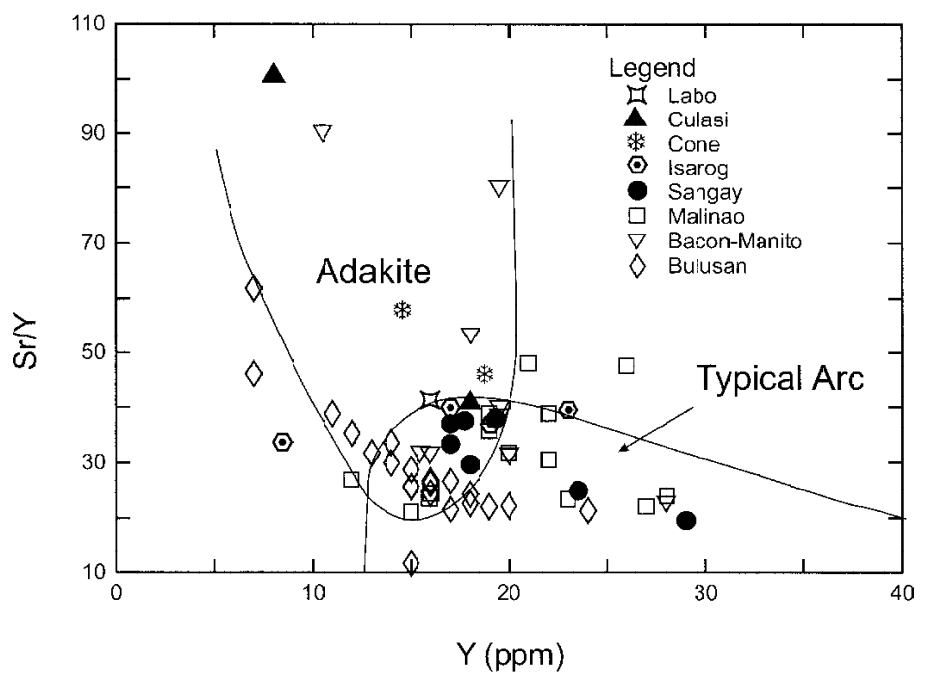

Fig. 7. Sr/Y versus Y plot of the Bicol Arc rocks. Representative samples of the NW segment volcanoes (Labo, Culasi and Cone) lie within the adakite field, with most of them plotting in the transition between adakites and typical arc rocks. Rocks from the central segment (Isarog, Sangay and Malinao) plot within the typical arc field. References as in Fig. 3. Fields after Defant and Drummond, 1990. 
the typical arc field. Majority of the SE segment volcanic center samples also plot in the adakite field (Bacon-Manito) with the rest of the samples plotting in the arc field or in the boundary between the adakite and typical arc fields. Since majority of the rocks are calcalkaline, no across or along arc tholeiitic - calc-alkaline - alkaline geochemical variation pattern was recognized for the Pleistocene volcanic rocks of the Bicol Arc. Plotted in Fig. 8 are the estimated compositions of lavas in terms of $\mathrm{K}_{2} \mathrm{O}, \mathrm{Na}_{2} \mathrm{O}$ and $\mathrm{CaO}$ from each volcanic center at basaltic composition $(\mathrm{MgO}=\sim 6 \mathrm{wt} \%)$. Since the lavas have experienced different degrees of fractionation during their residence in the magma chamber or during their ascent, it is essential to recalculate them back to basaltic composition so that they will have a common level of comparison. The trend lines used to estimate the basaltic equivalents for each volcano were derived from samples strictly with $>3 \mathrm{wt} \% \mathrm{MgO} . \mathrm{K}_{2} \mathrm{O}(6.0)$ and $\mathrm{Na}_{2} \mathrm{O}(6.0)$ concentrations generally decrease from the NW through the central to the SE segments of the arc whereas the $\mathrm{CaO}(6.0)$ increases from the NW to the SE (Fig. 8).

\section{DISCUSSIONS}

\subsection{Pleistocene Volcanic Arc: Geochemical Processes and Products}

Geochemical and petrographic analyses of the Pleistocene samples of the Bicol Arc reveal that magma mixing was a dominant factor in their magmatic evolution similar to what has been noted elsewhere (e.g., Yumul et al. 2003a, b; De Hoog et al. 2004). Major element plots in Harker diagrams define linear trends, which to a first order of approximation, suggest magma mixing. This process is confirmed from the petrography of the samples. Resorbed crystals and dusty appearance among plagioclases are typical signatures of magma mixing and these are common in the samples analyzed. The occurrence of plagioclase and pyroxene xenocrysts further supports this idea. Petrographic evidence such as undulatory extinction of plagioclase and ophacite also suggests explosive eruption during extrusion. Fractional crystallization is also evident from the behaviour of the different major elements with increasing $\mathrm{SiO}_{2}$ (Fig. 5). Crystallization of clinopyroxene, hornblende, plagioclase and magnetite are noted from the element trends on the Harker-type diagrams. Subduction processes played a major role in the generation of the Pleistocene magmas in the Bicol Arc as seen from the negative Ti-Nb anomaly in the majority of the rocks samples (e.g., Pearce and Peate 1995; Yumul et al. 2000). This suggests their affinity to mantle-wedge derived magmas with the possible exception of some samples from Culasi and Bacon-Manito. Although adakites from the older rock units of the Bicol Arc were possibly derived from magmas with slab-derived or lower crust-derived melt contributions (Andal 2002), the adakitic rocks from Culasi and Bacon-Manito might be related to fractional crystallization, specifically in the presence of an HREE- and Y receptor (e.g., apatite). This mechanism is similar to what has been noted in Northland, New Zealand and Camiguin and Pinatubo Volcano, Philippines (e.g., Green 1992; Castillo et al. 1998; Prouteau and Scaillet 2003).

Slab configuration, hypothesized from seismic data showing that the subducting slab under the northern portion of the peninsula plunges at a relatively steeper angle than in the south- 


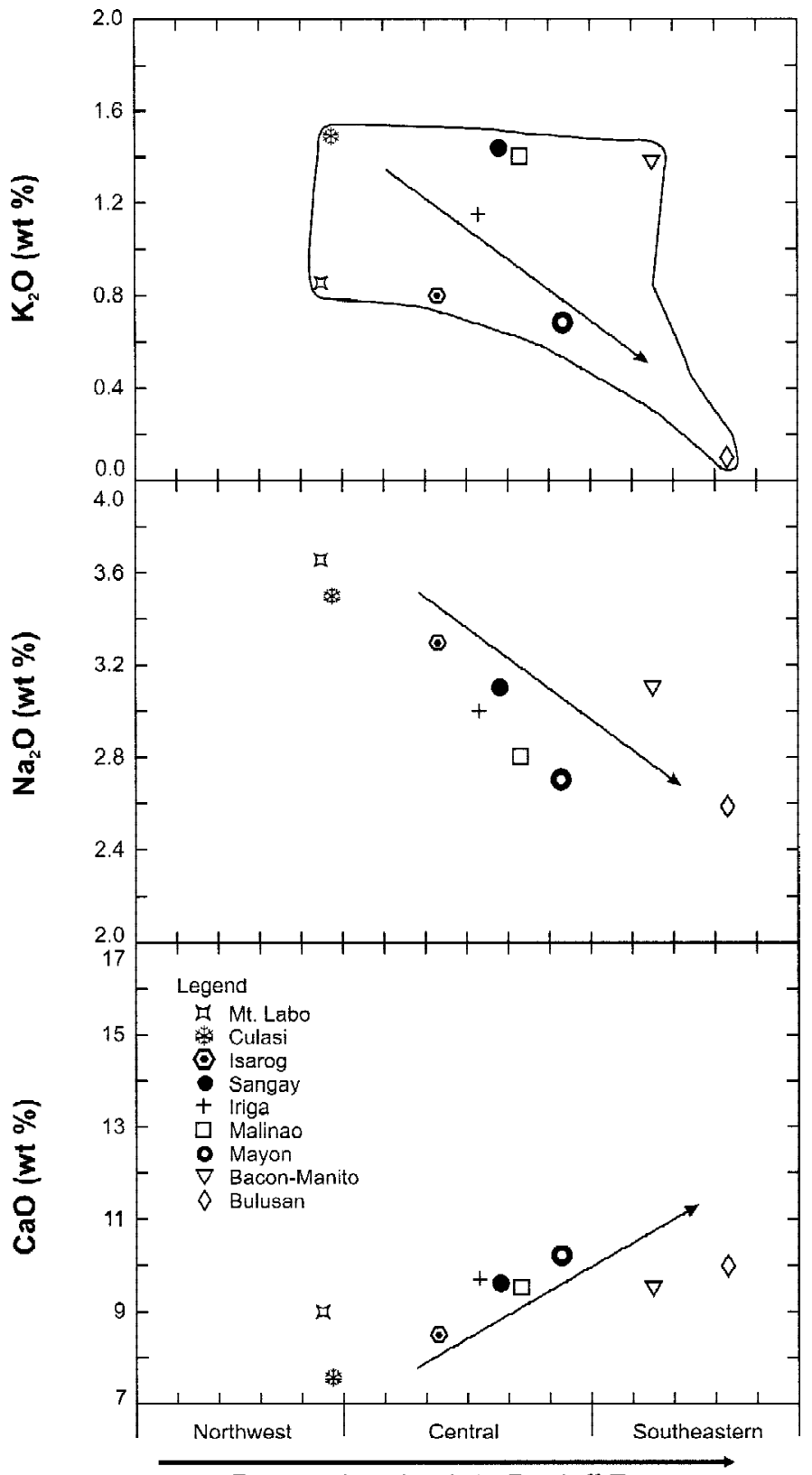

Decreasing depth to Benioff Zone

Fig. 8. Diagram showing the along-arc geochemical variation in the Bicol Arc in terms of $\mathrm{K}_{2} \mathrm{O}(6.0), \mathrm{Na}_{2} \mathrm{O}(6.0)$ and $\mathrm{CaO}(6.0)$. See text for discussion. Arrows drawn to show general trends of geochemical variation. In the $\mathrm{K}_{2} \mathrm{O}(6.0)$ diagram, field is drawn to show the generally decreasing $\mathrm{K}_{2} \mathrm{O}$ concentrations in the Pleistocene volcanic arc. 
ern portion [Philippine Institute of Volcanology and Seismology (PHIVOLCS) 2000] and the $250 \mathrm{~km}$ subducted slab (Aurelio 2000), suggests that the Benioff zone is shallowing towards the southeast underneath the Bicol Arc. If so, then this, accompanied by the generally decreasing $\mathrm{K}_{2} \mathrm{O}$ (wt\%) concentrations in the Pleistocene volcanic arc (Fig. 8), is consistent with the $\mathrm{K}-h$ relationship (Dickenson 1975). This is also recognized in other volcanic arc systems (e.g., Indonesia). The $\mathrm{K}-h$ relationship proposed for arc volcanism proposes that the $\mathrm{K}_{2} \mathrm{O}$ (wt\%) concentrations in the magmas positively correlate with the depth to the Benioff zone (Dickenson 1975). Aside from the difference in slab angle, another possibility to explain the along-arc variation in K composition is the difference in crustal thickness between the NW, Central and SE segments of the arc (e.g., Dimalanta and Yumul 2003). Estimates of the crustal thickness utilizing the Plank and Langmuir (1988) method suggest a thicker crust in the NW, progressively decreasing towards the SE segment (e.g., Listanco et al. 1997; Andal 2002). A combination of the difference in slab angle subduction and variation in crustal thickness may explain the observed K along-arc variation (e.g., Wallace and Carmichael 1999).

\subsection{Implications for Geohazard Assessment}

The petrographic and geochemical data obtained from this study are important in the assessment of geohazards related to the volcanic centers in the Bicol Arc considering the fact that it includes three active volcanoes. Many volcanic studies are aimed toward an assessment of the probability that volcanic eruptions will occur. In the case of active volcanoes, determining the explosive or destructive nature of the volcanic eruptions is also a major concern. Volcanoes are generally characterized as basaltic or rhyolitic depending on the composition of their lavas. Volcanoes that produce basaltic lavas are typified by relatively "quiet" or nonexplosive eruptions. This is attributed to the relatively lesser amount of silica that makes up the basaltic lavas. Thus, basaltic lavas are less viscous and flow relatively easily. Rhyolitic lavas, on the contrary, contain significant amounts of silica. This leads to higher viscosity of the lavas and, therefore, leads to more explosive or destructive eruptions (Perry et al. 2000). The hazards associated with volcanic eruptions include lava flows, pyroclastic flows, lahars and tephra falls. One of the most active volcanoes in the Philippines, Mayon, is predominantly andesitic in composition (Newhall 1977; Su and Huh 2002). There are forty-seven eruptions that had been recorded since 1616, the latest of which took place on July 26, 2001. Its most destructive eruption occurred on February 1, 1814 in which 1,200 people died mainly due to lahars. Violent explosions and ejection of pyroclastic materials have often characterized the volcanic activity in Mayon Volcano. Bulusan has erupted eighteen times since 1852 with the latest eruption recorded on November 27, 1994. In general, the Bulusan volcanic complex has lavas ranging in composition from basalt to dacite, although, it is dominantly andesitic in composition (Delfin 1991). Bulusan also showed evidence of phreatic explosions (Delfin 1991). Furthermore, the $\sim 11 \mathrm{~km}$ wide Irosin caldera (with its flattened north and northwest wall) and the extensive pyroclastic and tephra fall deposits to this direction, is strong evidence of very violent eruptions during the calderagenic stage of the complex. Later eruptions (e.g., 19181919 eruptions) of Bulusan were described as quiet extrusion of lavas onto the surface. Iriga is the least active of the three active volcanoes having had only one eruption recorded throughout 
its history (e.g., Listanco 1990). However, the southern flank of its cone collapsed causing a debris avalanche extending several kilometers, damming a river and creating a new lake.

In summary, the hazards generally associated with the eruptions of the three active volcanoes in the Bicol Arc are lava flows, pyroclastic flows, airfall tephra, debris avalanche and lahars. These geohazards, specifically debris avalanche and lahars, are known to have wrought havoc to the surrounding communities. If the knowledge on the geochemistry of the Bicol Arc, particularly on the active volcanoes, gained from this study, can be combined with results of studies of their repose periods, appropriate planning and mitigation can be made to lessen the impacts of the associated geohazards and risks.

\section{CONCLUSIONS}

Our study of the most recent magmatic episode in the Bicol Arc resulted to the recognition of the dominance of basaltic andesite and andesite. Most of the rocks have a calc-alkaline affinity. A few of the samples from Mayon and Iriga are the only ones displaying low-K arc tholeiitic rocks. Petrography and geochemistry of the rocks suggest that fractional crystallization and magma mixing were operative during their formation. They also show evidence for explosive eruptions. The recognition of the geochemical characteristics of this volcanic arc group, particularly the three active volcanoes, is useful in determining the type of volcanic products and their associated hazards.

Acknowledgements This study was made possible through a grant provided by the Department of Science and Technology - Philippine Council for Advanced Science and Technology Research and Development and the University of the Philippines - National Institute of Geological Sciences. Geochemical analyses were done at the Ocean Research Institute, University of Tokyo and in the Department of Geology and Mineralogy, Kyoto University. Some petrographic work was also done in the Department of Earth Sciences, Kanazawa University. Reviews by Dr. Paterno Castillo and another anonymous referee are appreciated. This is NIGS Contribution No. 2005-02.

\section{REFERENCES}

Andal, E. S., 2002: Geological and geochemical characterization of the Plio-Pleistocene to Recent volcanic rocks of the Southeastern Luzon volcanic arc chain: Implications to arc evolution. Master Thesis, Univ. Philippines, $154 \mathrm{pp}$.

Arculus, R. J., 1994: Aspects of magma genesis in arcs. Lithos, 33, 189-208.

Aurelio, M. A., 2000: Tectonics of the Philippines revisited.J. Geol. Soc. Phil., 55, 119-183.

Castillo, P. R., J. H. Natland, Y. Niu, and P. F. Lonsdale, 1998: Sr, Nd and Pb isotopic variation along the Pacific-Antarctic risecrest, 53-57 degrees S: implications for the composition and dynamics of the South Pacific upper mantle. Earth Planet. Sci. Lett., 154, $109-125$. 
Castillo, P. R., and C. G. Newhall, 2004: Geochemical constraints on possible subduction components in lavas of Mayon and Taal volcanoes, Southern Luzon, Philippines. J. Petrol., 45, 089-1108.

Chertkoft, D. G., and J. E. Gardner, 2004: Nature and timing of magma interactions before, during and after the caldera-forming eruption of Volcán Ceboruco, Mexico. Contrib. Mineral. Petrol., 146, 715-735.

Defant, M. S., and M. S. Drummond, 1990: Derivation of some modern arc magmas by melting of younger subducted lithosphere. Nature, 347, 662-665.

De Hoog, J. C. M., K. M. Hattori, and R. P. Hoblitt, 2004: Oxidized sulfur-rich mafic magma at Mount Pinatubo, Philippines. Contrib. Mineral. Petrol., 146, 750-761.

Delfin, F. G. Jr., 1991: Petrogenesis of Mt. Bulusan Volcanic Complex, Bicol Arc, Philippines. Master Thesis, Univ. South Florida, 122 pp.

Delfin, F.G., C. Panem-Conrado and M. J. Defant, 1993: Eruption history and petrochemistry of the Bulusan volcanic complex, implications for the hydrothermal system and volcanic hazards of Mount Bulusan, Philippines. Geothermics, 22, 417-434.

Dickenson, W. R., 1975: Potash-depth (K-h) relations in continental margin and intra-ocean magmatic arcs. Geology, 3, 53-56.

Dimalanta, C. B., and G. P. Yumul, Jr., 2003: Magmatic and amagmatic contributions to crustal growth of an island-arc system: The Philippine example.Inter. Geol. Rev., 45, 922-935.

Divis, A. F., 1980: The petrology and tectonics of recent volcanism in the central Philippine Islands. AGU Geophys. Mono., 23, 127-124.

Green, T. H., 1992: Experimental phase equilibrium studies of garnet-bearing I-type volcanics and high-level intrusives from Northland, New Zealand.Trans. Royal Soc. Edinburgh. Earth Sci., 83, 429-438.

Haraguchi, S., T. Ishii, J. Kimura, and Y. Ohara, 2003: Formation of tonalite from basaltic magma at the Komahashi-Daini Seamount, northern Kyushu-Palau Ridge in the Philippine Sea, and growth of Izu-Ogasawara (Bonin)-Mariana arc crust. Contrib. Mineral. Petrol., 145, 151-168.

Japan International Cooperation Agency (JICA), 1999: Report on Regional Survey for Mineral Resource in the Bicol Area, Rep. the Philippines.

Knittel-Weber, C., and U. Knittel, 1990: Petrology of the volcanic rocks on the eastern flank of Mount Malinao, Bicol Arc (S. Luzon, Philippines). J. SE Asian Earth Sci., 4, 267 280.

KRTA Limited, 1986: A study of precious metal mineralization: styles, models and prospects in the Bicol volcanics Luzon Philippines, Unpubl. Rpt., 1-70.

Lagmay, A. M. F., B. van Wyk de Vries, N. Kerle, and D. Pyle, 2000: Volcano instability induced by strike-slip faulting. Bull. Volcanol., 62, 331-346.

Lee, H. F., T. F. Yang, T. F. Lan, S. R. Song, and S. Tsao, 2005: Fumarolic gas composition of the Tatun Volcano Group, northern Taiwan. Terr. Atmos. Ocean. Sci., 16, 843-864.

Listanco, E. L., 1990: The geology and geochemistry of Iriga Volcano, southeastern Luzon, Philippines. Master Thesis, Univ. Tokyo, 166 pp. 
Listanco, E. L., G. P. Yumul, Jr., and R. T. Datuin, 1997: On the thickness of the Philippine Crust: Application of the Plank-Langmuir Systematics. J. Geol. Soc. Phil., 52, 20-24.

Mullen, E. D., 1983: $\mathrm{MnO} / \mathrm{TiO}_{2} / \mathrm{P}_{2} \mathrm{O}_{5}$ : a minor element discriminant for basaltic rocks of oceanic environments and its implications for petrogenesis. Earth Planet. Sci. Lett., 62, 53-62.

Newhall, C. G., 1977: Geology and Petrology of Mayon Volcano, Southeastern Luzon, Philippines. Master Thesis, Univ. California, $291 \mathrm{pp}$.

Newhall, C. G., and R. S. Punongbayan, 1996: Fire and mud: eruptions and lahars of Mount Pinatubo, Philippines. PHIVOLCS Quezon City, Philippines and University of Washington Press, Seattle.

Ozawa, A., T. Tagami, E. L. Listanco, C. B. Arpa, and M. Sudo, 2004: Initiation and propagation of subduction along the Philippine Trench: evidence for the temporal and spatial distribution. J. Asian Earth Sci., 23, 105-111.

Pearce, J. A., and D.W. Peate, 1995: Tectonic implications of the composition of volcanic arc magmas. An. Rev. Earth Planet. Sci., 23, 251-285.

Pecerrillo, A. R., and S. R. Taylor, 1976: Geochemistry of Eocene calc-alkaline volcanic rocks from the Kastamonu area, northern Turkey. Contrib. Mineral. Petrol., 58, 63-81.

Pecoraino, G., and S. Giammanco, 2005: Geochemical characterization and temporal changes in parietal gas emissions at Mt. Etna (Italy) during the period July 2000-July 2003. Terr. Atmos. Ocean. Sci., 16, 805-841.

Perry, F. V., B. M. Crowe, and G. A. Valentine, 2000: Analyzing volcanic hazards at Yucca Mountain. Los Alamos Sci., 26, 492-493.

Philippine Institute of Volcanology and Seismology (PHIVOLCS) - Volcano Monitoring and Eruption Prediction Division, 2000: List of Volcanoes in the Philippines, (www.phivolcs. dost.gov.ph).

Plank, T., and C. Langmuir, 1988: An evaluation of the global variations in the major element chemistry of arc basalts. Earth Planet. Sci. Lett., 90, 349-370.

Prouteau, G., and B. Scaillet, 2003: Experimental constraints on the origin of the 1991 Pinatubo dacite. J. Petrol., 44, 2203-2241.

Sajona, F. G., H. Bellon, R. C. Maury, M. Pubellier, R. D. Quebral, J. Cotten, F. E. Bayon, E. Pagado, and P. Pamatian, 1996: Tertiary and Quaternary magmatism in Mindanao and Leyte, Philippines: geochronology, geochemistry and tectonic setting.J. SE Asian Earth Sci., 15, 121-153.

Su, C. C., and C. A. Huh, 2002: Atmospheric ${ }^{210} \mathrm{Po}$ anomaly as a precursor of volcano eruptions. Geophys. Res. Lett., 29, 10.109/2001GL010856.

Sun, S. S., and W. F. McDonough, 1989: Chemical and isotopic systematics of oceanic basalts: Implications for mantle compositions and processes. In: Saunders, A. D., and M. J. Norry (Eds.), Magmatism in the Ocean Basins. Geol. Soc. Spec. Pub., 42, 313-345.

Wallace, P. J., 2001: Volcanic $\mathrm{SO}_{2}$ emissions and the abundance and distribution of exsolved gas in magma bodies. J. Volcanol. Geochem. Res., 108, 85-106.

Wallace, P. J., and I. S. E. Carmichael, 1999: Quaternary volcanism near the valley of Mexico: implications for subduction zone magmatism and the effects of crustal thickness variations on primitive magma compositions. Contrib. Mineral. Petrol., 135, 291-314. 
Yumul, G. P. Jr., C. B. Dimalanta, H. Bellon, D. V. Faustino, J. V. De Jesus, R. A. Tamayo, Jr., and F. T. Jumawan, 2000: Adakitic lavas in the Central Luzon back-arc region (Philippines): lower crust partial melting products? Island Arc, 9, 499-512.

Yumul, G. P. Jr., C. B. Dimalanta, R. A. Tamayo, Jr., and H. Bellon, 2003a: Silicic arc volcanism in Central Luzon, Philippines: Characterization of its space, time and geochemical relationship. Island Arc, 12, 207-218.

Yumul, G. P. Jr., C. B. Dimalanta, V. B. Maglambayan, and R. A. Tamayo, Jr., 2003b: Mineralization controls in island arc settings: Insights from Philippine metallic deposits. Gondwana Res., 6, 767-776. 